\title{
Commercial hunting to supply urban markets threatens mammalian biodiversity in Sapo National Park, Liberia
}

ELIZAB B Th GREENGRAS

\begin{abstract}
This survey was part of a situational analysis of bushmeat hunting and trade in Sapo National Park in south-east Liberia. Increased private-sector investment in natural resource extraction and industrial-scale agribusiness outside the Park is anticipated to increase hunting pressure and lead to further declines in biodiversity unless informed, assertive actions are taken to protect it more effectively. Two commercial hunting camps on the Park's southern boundary were surveyed for 1 month each. Information on the catch of all professional hunters in these camps was documented. The results revealed a high diversity of species but significant and probably unsustainable bushmeat extraction rates. Eighty-two chimpanzees Pan troglodytes verus, including eight live infants, were recorded in the survey. Most of the bushmeat harvested was destined for Monrovia and other major towns. A concerted effort needs to be made to shut down these commercial camps but the potentially significant contribution that commercial trade makes to urban areas suggests that this can only be achieved if Liberia develops alternative sectors in domestic meat production to feed the growing urban population.
\end{abstract}

Keywords Bushmeat, Liberia, Pan troglodytes verus, professional hunting, Sapo National Park

\section{Introduction}

L iberia lies within the Guinea Forests of West Africa biodiversity hotspot, where there is significant loss of habitat for endemic species (Myers et al., 2000). Liberia lies entirely in the western portion of this hotspot, the Upper Guinea forest region, encompassing $>4$ million ha of forest (Christie et al., 2007) in two blocks, in the north-west and south-east of the country. The diversity of mammals is high. There are nine species of diurnal primates, six of which are of conservation concern: the western chimpanzee Pan troglodytes verus, the western red colobus Procolobus badius, the western black-and-white colobus Colobus polykomos, the Diana monkey Cercopithecus diana, the sooty

\footnotetext{
Elizabeth Greengrass* Born Free Foundation, Holmwood, Broadlands Business Campus, Langhurstwood Road, Horsham, RH12 4PN, UK

E-mail liz@bornfree.org.uk

${ }^{\star}$ Previously at: FFI Liberia, Congo Town, Monrovia, Liberia

Received 28 September 2014. Revision requested 7 November 2014.

Accepted 20 January 2015. First published online 25 May 2015.
}

mangabey Cercocebus atys, and the olive colobus Procolobus verus. The pygmy hippopotamus Choeropsis liberiensis, a rare and threatened species, is found only in the Upper Guinea forests. There are also seven species of duikers, including the Endangered Jentink's duiker Cephalophus jentinki and the Vulnerable zebra duiker Cephalophus zebra.

Liberia is considered a priority country for conservation but its protected area network is underdeveloped and it has only one National Park. Sapo National Park, located in the south-east in Sinoe, Grand Gedeh and River Gee Counties (Fig. 1), was established in 1983 and extended in 2003 to 180,363 ha. It constitutes a significant portion of the remaining south-east rainforest block. The Park may support $>1,500$ chimpanzees, an estimated $20-25 \%$ of the national population (N'Goran et al., 2010; Tweh et al., 2014).

Protection of the Park remains a challenge. Some evidence suggests that there has been an increase in hunting pressure (Tweh et al., 2014) since the end of the last civil conflict in 2003. There are commercial hunting camps in the Park's vicinity, and illegal gold mining occurred unimpeded in the Park until 2011. In 2010 a survey estimated that there were 18,00o miners in nine camps in the Park (Kayjay, 2010). This estimate could not be verified independently but it suggested a significant increase from an unconfirmed estimate of 2,00o miners, which had been widely quoted previously, and the hundreds thought to have inhabited the Park during both civil wars (1989-2003; Collen et al., 2011). Artisanal mining causes environmental degradation but the dependence of miners on bushmeat is likely to have placed additional hunting pressure on wildlife. Vogt (2011) documented an increase in hunting signs during 2008-2010 and compared her findings to an earlier survey in which few signs of human disturbance were reported (Waitkuwait, 2003).

Driven by commercialization of the trade, and facilitated by increased access and improved technologies (Bennett, 2008), most unregulated hunting of larger-bodied mammalian species is unsustainable (Peres, 2010). Hunting can have disastrous impacts on the ecological integrity of tropical forests and can lead to significant declines. It is considered the primary cause of primate loss in West Africa (Covey \& McGraw, 2014). Group-living, conspicuous primates, in particular the great apes that have low intrinsic rates of population increase and long-term infant dependency, are especially vulnerable. The extirpation of species can lead to the decline of their predators (Henschel et al., 2011), 


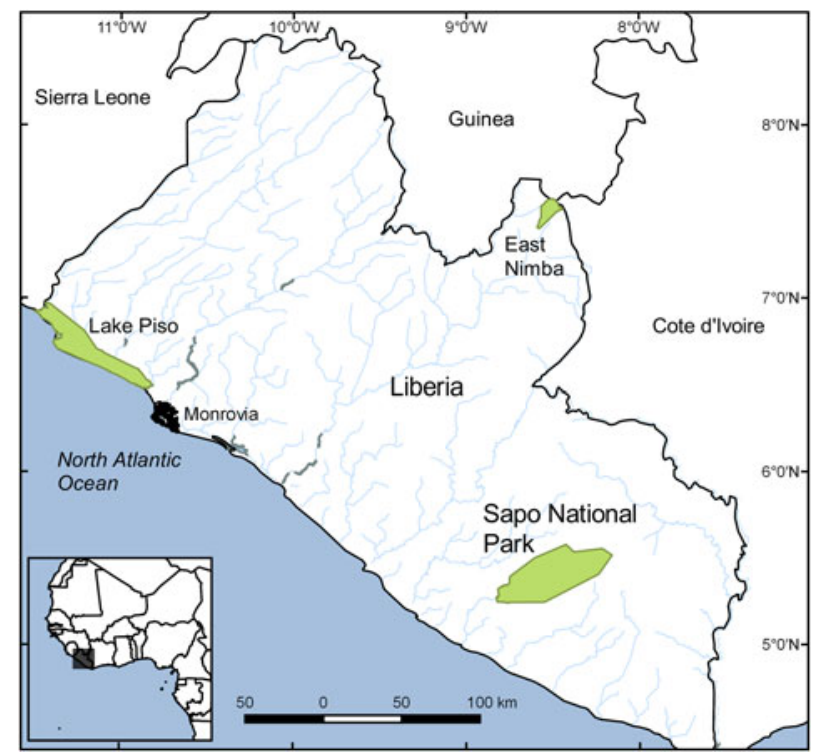

FIG. 1 Officially designated protected areas in Liberia: Sapo National Park, Lake Piso Multiple Use Reserve, and East Nimba Nature Reserve.

and with $>80 \%$ of tree species in the Afrotropics relying on animal dispersal (Beaune et al., 2013) ecological processes such as plant regeneration can be disrupted ( $\mathrm{Fa} \&$ Brown, 2009), with far-reaching consequences for plant diversity, composition and forest structure.

Outside Sapo National Park the need for economic development is driving extraction of natural resources and placing ever-increasing pressure on the integrity of the Park and the surrounding forest. The extraction of timber and minerals is expected to generate the majority of the country's gross domestic product in the next couple of decades (MPEA, 2010) but the establishment of road networks and improvements in transportation links increase access to closed forest, and consequently hunting pressure on wildlife. In-migration of people looking for work can increase the local population, placing additional pressure on wildlife. Community rights mean that even where companies mitigate the impacts of their operations on biodiversity, they are unable to control hunting within their concessions, even if project roads increase access to the forest, complicating sustainability management. Wildlife habitat around protected areas is vital for ecological functions, and increased private-sector investment outside the Park may lead to further declines in biodiversity within the Park unless appropriate measures are implemented to control hunting and protect the Park effectively.

The aim of this survey was to investigate the nature of commercial hunting in the Park and its impact on wildlife populations. It was part of a larger study on the dynamics of bushmeat hunting and trade in the area. Despite the presence of commercial hunting camps, little was known about bushmeat extraction rates or the destination of bushmeat and how it was transported.
I sought to quantify the rate of harvest and offtake, identify the species targeted by commercial hunters, identify the hunting and transportation methods employed, identify the intended destination for the bushmeat, and estimate the income generated by commercial hunters. It was hoped that the resulting situational analysis would play a key role in assessing the level of threat posed by these camps, and guide decision makers on the most appropriate action to safeguard the Park from overexploitation. At the time of the survey in 2010 the Forest Development Authority was planning the voluntary eviction of artisanal miners from the Park but although the results of this survey were presented and it was recommended that hunting and mining camps be closed simultaneously, this did not occur. In the absence of an adaptive management strategy on the part of the Forest Development Authority, and with no formal expression of intention to close the camps, it is likely that the camps remain active. This study thus highlights the perilous state of protected areas in West and Central Africa as a result of the unregulated bushmeat trade.

\section{Methods}

Given the location of the camps in close proximity to Sapo National Park, some aspects of the bushmeat hunting carried out were probably illegal. As Fauna \& Flora International works closely with the Park authorities it was not possible to gain consent to access the hunting camps directly. In addition, hunters are reticent about disclosing their work to foreigners, whom they perceive as disapproving of bushmeat trade and consumption. However, given that bushmeat trade is an integral and cultural part of rural and urban life in the region, benefiting individuals and communities alike, it is only to outsiders that it appears to be clandestine in nature. A Liberian research assistant working for the Forest Conservation Corps, a local environmental NGO in south-east Liberia, was thus able to gain access to the camps. The research assistant was known to the hunters and was from the same community as at least one of them. He was careful not to express disapproval or a negative attitude towards their activities. He and I only ever met in Monrovia, never in Greenville, the local town, where we could have been seen together.

Before the surveys commenced I ensured that the research assistant was able to identify fauna to the species level. He was shown a comprehensive series of photographs of Liberia's mammalian fauna to ensure correct identification, and some repeated training was conducted between the two surveys.

The research assistant surveyed two camps, Neechebu and Chanedae, during 1 April-1 May and 24 May-23 June 2010, respectively. All professional hunters present in each camp during the survey period participated. Professional 
hunters were men who had moved from their communities into these camps in the forest to hunt animals on a commercial and full-time basis. Each hunter had a small number of regular buyers, mostly women, who were typically from the same ethnic group as the hunter. Traders purchased the meat directly from the hunters and transported it to market for sale. As the traders spent prolonged periods in the hunting camps, the research assistant interviewed them informally. Communication was in Pidgin English or Sapo. In Chanedae the research assistant was assisted by two colleagues.

The research assistant stayed in the camp during the whole survey period and visited each hunter in turn at the end of each shift, when they returned to their houses. He observed their catches, and recorded information on each carcass. There was a high occurrence of threatened species, indicating that hunters were at ease with this information being recorded. It did not appear that part of the catch was hidden.

The following data were collected for each carcass: species, age (infant, juvenile, adult), sex, condition (fresh, smoked, rotten), weapon used, hunter (assigned an anonymous label), and whether the animal was hunted during the day or night. Species names were recorded in English or Pidgin English. Most carcasses were fresh; hunters brought their catch to camp daily and traders smoked the meat after they had purchased it. Data on the price and destination of the meat were also collected. It was unclear if the recorded price was always the final sale price, or the asking price, and therefore these data can be considered only an estimate of the revenue generated by hunters. At the end of each survey I received the data. In addition to the data gathered by the research assistant, I received informal reports and photographic evidence from other sources in the vicinity of the Park of an alternative means by which bushmeat was transported in the area.

To estimate biomass, adult carcasses were assigned the mean of the adult range described in Kingdon (1997), and immature individuals were assigned half these mean values. The mean mass for each sex was calculated if the relevant data were available. The mean mass of male and female chimpanzees reported by Kingdon (1997) appeared to underestimate true values, and therefore adult males were assigned what was considered a more realistic mean mass of $55 \mathrm{~kg}$, and females $40 \mathrm{~kg}$. Live infant chimpanzees and monkeys were assigned an approximate mass of 5 and 1 $\mathrm{kg}$, respectively.

The research assistant was not a specialist and was unable to determine the sex of reptiles, pangolins or the potto Perodicticus potto. Pangolins, porcupines and mongooses were not identified to the species level, nor were monkeys at Neechebu. This latter omission could have been avoided had I been able to accompany the research assistant to the field, and it was considered to be a result of inadequate in-situ training, as he was able to identify monkeys to the species level prior to the first survey. Consequently, further training was provided between surveys, and certain measures (e.g. number of mammalian species, biomass harvested) could only be estimated. Three species of monkeys were identified at Chanedae and it was assumed these same species had been observed at Neechebu. All were threatened species and although it was not the intention to overestimate the proportion of the catch composed of threatened species, the assumption was considered justified because the majority of primates in Sapo National Park are of conservation concern. Porcupines were assumed to be the smaller brush-tailed porcupine Atherurus africanus, which appears to be more abundant than the crested porcupine Hystrix cristata (E. Greengrass, pers. obs.), and this ensured a conservative estimate of biomass, although only one carcass was recorded. Similarly, pangolins were assumed to be the smaller, terrestrial, white-bellied pangolin Phataginus tricuspis, because the black-bellied pangolin Uromanis tetradactyla is mainly arboreal and may be more difficult to encounter, and calculating biomass based on the giant pangolin Smutsia gigantea could have resulted in an overestimation. The research assistant did not identify any Ogilby's duiker Cephalophus ogilbyi but he may have misidentified them as Bay duiker Cephalophus dorsalis, as both are known locally as red deer. Both are categorized as Least Concern, and the mean mass of duiker was taken as the mean adult mass for both species. Finally, mongooses were not identified to species but only two carcasses were observed and therefore the mass of each carcass was taken as the mean of the mean values reported for the slender mongoose Herpestes sanguineus, the marsh mongoose Atilax paludinosus and the common cusimanse Crossarchus obscurus. The Liberian mongoose Liberiictis kuhni was not included because it appears to be particularly rare (Greengrass, 2013). Despite these discrepancies the research assistant had a good general knowledge of the mammalian fauna. The data appeared to reflect what is known about commercial hunting and the relative abundance of various mammalian species.

\section{Results}

Based on his work and his knowledge of the area, the research assistant estimated there were five commercial hunting camps close to the southern boundary of the Park. These camps were established by communities fleeing civil war in the 1990s but it was unclear if they had been occupied continuously since then or if they had been reoccupied more recently. Neechebu, the larger camp, was considered the headquarters by the hunters and had a daily market. Chanedae, further east, was a more scattered settlement of 10-15 permanent houses and temporary dwellings. The number of dwellings at Neechebu was not recorded but the greater number of hunters present indicates a larger 
TABLE 1 The proportions of various species groups in the total bushmeat harvest, in terms of number of carcasses and biomass.

\begin{tabular}{|c|c|c|c|c|c|}
\hline \multirow[b]{2}{*}{ Species groups } & \multicolumn{2}{|l|}{ Neechebu } & \multicolumn{2}{|l|}{ Chanedae } & \multirow[b]{2}{*}{$\begin{array}{l}\text { Overall mean } \\
\% \text { total catch }\end{array}$} \\
\hline & $\begin{array}{l}\% \text { total catch } \\
\text { (no. carcasses) }\end{array}$ & $\begin{array}{l}\% \text { total } \\
\text { biomass }\end{array}$ & $\begin{array}{l}\% \text { total catch } \\
\text { (no. carcasses) }\end{array}$ & $\begin{array}{l}\% \text { total } \\
\text { biomass }\end{array}$ & \\
\hline Primates & 52.51 & 29.37 & 29.19 & 16.44 & 40.85 \\
\hline Duikers & 30.29 & 26.56 & 52.56 & 45.13 & 41.43 \\
\hline Other ungulates ${ }^{\star}$ & 14.43 & 37.18 & 16.16 & 37.86 & 15.30 \\
\hline Rodents & 0.54 & 0.20 & 1.04 & 0.44 & 0.79 \\
\hline Pangolins & 2.06 & 0.29 & 0.78 & 0.11 & 1.42 \\
\hline Birds & 0.09 & & 0.09 & & 0.09 \\
\hline Elephant & 0.09 & 6.40 & & & 0.045 \\
\hline Small carnivores & & & 0.17 & 0.02 & 0.09 \\
\hline
\end{tabular}

${ }^{\star}$ Pygmy hippopotamus, water chevrotain, bush pig, bushbuck

settlement. Twenty-six hunters ( 15 full-time and 11 parttime) were recorded in Neechebu, and 16 full-time hunters in Chanedae. The majority came from Sinoe County in the south-east and Nimba County in north-central Liberia. Full-time hunters worked both a nightshift (19.00-06.30) and a day shift (12.00-18.00). Part-time hunters worked 4-10 days per month and were transient, moving between camps when they needed to raise cash. Full-time hunters lived with their wives and children, indicating permanent residency in the camps.

At Neechebu 1,115 carcasses and an estimated 18 mammalian species were recorded, and at Chanedae 1,150 carcasses and an estimated 16 species were recorded. For both camps this translates to 36 carcasses per day, which was unexpectedly consistent given that the number of hunters in Neechebu was higher. Duiker, other ungulate species, and primates comprised $>97 \%$ of the combined total number of carcasses for both camps. Commercial hunting was discriminatory (facilitated by the use of shotguns), targeting a limited number of large-bodied mammals (Table 1). Marginally more animals were hunted during the night shift 57 and $59 \%$ of the catch in Neechebu and Chanedae, respectively). Hunting by shotgun predominated in both camps (94 and $99 \%$ of the catch in Neechebu and Chanedae, respectively), with the remainder of carcasses trapped in snares. Only a small proportion of the catch was rotten (6 and $0.4 \%$ of carcasses in Neechebu and Chanedae, respectively), and rodents contributed little to the biomass of bushmeat harvested in either camp (Table 1). Duikers comprised $41.43 \%$ of the number of carcasses in the overall catch, followed by primates (40.85\%), and other ungulates (15.30\%).

At Neechebu an estimated $58 \%$ of the carcasses were of species of conservation concern (IUCN, 2014), rising to $64 \%$ when water chevrotain Hyemoschus aquaticus, a species protected under Liberian law, was included. The equivalent estimates at Chanedae were 38 and $45 \%$, respectively. Sixty-three carcasses of Endangered red colobus and 185 of Vulnerable Diana monkeys were recorded at Chanedae, and one Vulnerable elephant Loxodonta africana (a juvenile male) was recorded at Neechebu. Six Endangered pygmy hippopotuses were recorded, four in Neechebu and two in Chanedae. Of additional concern was the relatively large number of chimpanzees $(n=82)$. At Neechebu 51 chimpanzee carcasses were recorded and seven live infants captured. Females comprised $69 \%$ of the catch. At Chanedae 23 chimpanzees were killed and one live infant was captured; in contrast, $63 \%$ of the catch $(n=15)$ was male. These sex biases were unexpected but may be idiosyncratic.

More than $18,000 \mathrm{~kg}$ of meat was harvested at each camp (Table 2), with duiker, other ungulates and primates contributing most to the overall biomass (Tables 1 \& 2). An estimated USD 26,290 and USD 26,511 was generated at Neechebu and Chanedae, respectively, during the monthlong surveys. On average, hunters from Chanedae earned USD 1,657 each, and in Neechebu full-time hunters earned USD 1,354-1,825. Bushmeat was being sold at USD 1.43 per $\mathrm{kg}$ in Neechebu and USD 1.46 per kg in Chanedae, a consistency that could be expected if commercial hunting operations at both camps were coordinated.

The main destination for the bushmeat (approximately half of all carcasses) was Monrovia, with other destinations including the towns of Greenville, Ganta and Zwedru (Table 3). At Neechebu most of the produce not destined for Monrovia went to Greenville, with only a small proportion going to Zwedru and Ganta. At Chanedae similar and sizeable proportions went to Ganta and Greenville. These results suggest that destination may be a product of demand (Monrovia is the largest town), distance (excluding Monrovia, a large proportion of the catch was destined for the closest town of Greenville), and the origin of the hunters and traders. Many hunters were reportedly from Sinoe and Nimba Counties and the large proportion of the catch at Chanedae that was destined for Nimba's commercial capital, Ganta, suggested that this camp might support a higher proportion of hunters from Nimba. Almost $90 \%$ of the chimpanzees harvested were destined for Monrovia. The reason for this is not clear. 
TABLE 2 Species recorded during two month-long surveys of two commercial hunting camps, Neechebu and Chanedae, in the vicinity of Sapo National Park, Liberia (Fig. 1), with IUCN Red List status, number of carcasses, percentage of total catch, total mass and percentage of total biomass.

\begin{tabular}{|c|c|c|c|c|c|c|c|c|c|}
\hline \multirow[b]{2}{*}{ Species } & \multirow[b]{2}{*}{$\begin{array}{l}\text { Red List } \\
\text { status }^{*}\end{array}$} & \multicolumn{4}{|l|}{ Neechebu } & \multicolumn{4}{|l|}{ Chanedae } \\
\hline & & $\begin{array}{l}\text { No. of } \\
\text { carcasses }\end{array}$ & $\begin{array}{l}\% \text { total } \\
\text { catch }\end{array}$ & $\begin{array}{l}\text { Total mass } \\
(\mathrm{kg})\end{array}$ & $\begin{array}{l}\% \text { total } \\
\text { biomass }\end{array}$ & $\begin{array}{l}\text { No. of } \\
\text { carcasses }\end{array}$ & $\begin{array}{l}\% \text { total } \\
\text { catch }\end{array}$ & $\begin{array}{l}\text { Total } \\
\text { mass } \\
(\mathrm{kg})\end{array}$ & $\begin{array}{l}\% \text { total } \\
\text { biomass }\end{array}$ \\
\hline $\begin{array}{l}\text { Bay/Ogilby's Cephalophus } \\
\text { dorsalis/Cephalophus ogilbyi }\end{array}$ & $\mathrm{LC}$ & 129 & 11.56 & $2,272.13$ & 12.38 & 175 & 15.2 & $3,175.5$ & 17.53 \\
\hline Black duiker Cephalophus niger & $\mathrm{LC}$ & 49 & 4.39 & 940 & 5.12 & 63 & 5.47 & 1,260 & 6.96 \\
\hline $\begin{array}{l}\text { Maxwell's duiker Philantomba } \\
\text { maxwellii }\end{array}$ & LC & 109 & 9.77 & 804 & 4.38 & 279 & 24.24 & 2.200 & 12.15 \\
\hline Zebra duiker Cephalophus zebra & VU & 51 & 4.57 & 857.5 & 4.67 & 88 & 7.65 & 1,540 & 8.50 \\
\hline Bushbuck Tragelaphus scriptus & LC & 53 & 4.75 & $2,450.5$ & 13.35 & 52 & 4.52 & $2,577.5$ & 14.23 \\
\hline $\begin{array}{l}\text { Red river hog Potamochoerus } \\
\quad \text { porcus }\end{array}$ & LC & 35 & 3.14 & 2,760 & 15.04 & 36 & 3.13 & 2,800 & 15.46 \\
\hline $\begin{array}{l}\text { Water chevrotain Hyemoschus } \\
\text { aquaticus }\end{array}$ & $\mathrm{LC}$ & 69 & 6.18 & 702.7 & 3.83 & 96 & 8.34 & $1,024.75$ & 5.66 \\
\hline $\begin{array}{l}\text { Pygmy hippopotamus } \\
\text { Choeropsis liberiensis }\end{array}$ & $\mathrm{EN}$ & 4 & 0.36 & 910 & 4.96 & 2 & 0.17 & 455 & 2.51 \\
\hline Elephant Loxodonta cyclotis & VU & 1 & 0.09 & 1,175 & 6.40 & & & & \\
\hline $\begin{array}{l}\text { Chimpanzee Pan troglodytes } \\
\text { verus }\end{array}$ & $\mathrm{EN}$ & 58 & 5.20 & 2,250 & 12.26 & 24 & 2.09 & 1,080 & 5.96 \\
\hline $\begin{array}{l}\text { Monkey species Diana monkey } \\
\text { Cercopithecus diana }\end{array}$ & $\mathrm{VU}$ & 528 & 47.31 & $3,139.24$ & 17.11 & 185 & 16.07 & 782.275 & 4.32 \\
\hline Red colobus Procolobus badius & $\mathrm{EN}$ & & & & & 63 & 5.47 & 591.5 & 3.27 \\
\hline Sooty mangabey Cercocebus atys & VU & & & & & 64 & 5.56 & 523.5 & 2.89 \\
\hline Mongoose species & & & & & & 2 & 0.17 & 3.62 & 0.02 \\
\hline Cane rat Thryonomys sp. & LC & 5 & 0.45 & 33.25 & 0.18 & 12 & 1.04 & 79.8 & 0.44 \\
\hline Porcupine species & LC & 1 & 0.09 & 2.75 & 0.015 & & & & \\
\hline Pangolin species & $\mathrm{LC}$ & 23 & 2.06 & 52.9 & 0.29 & 9 & 0.78 & 20.7 & 0.11 \\
\hline Eagle (Accipitridae) & & 1 & 0.09 & & & 1 & 0.09 & & \\
\hline Total & & 1,116 & & $18,349.97$ & & 1,151 & & $18,114.15$ & \\
\hline
\end{tabular}

${ }^{*}$ LC, Least Concern; EN, Endangered; VU, Vulnerable

TABLE 3 Percentage of the total catch from the hunting camps at Neechebu and Chanedae destined for various towns and communities.

\begin{tabular}{llc}
\hline Destination & $\begin{array}{l}\text { \% total catch, } \\
\text { Neechebu }\end{array}$ & $\begin{array}{l}\text { \% total catch, } \\
\text { Chanedae }\end{array}$ \\
\hline Monrovia & 56.99 & 45.91 \\
Greenville & 26.96 & 18.73 \\
Zwedru & 3.60 & 3.66 \\
Ganta & 0.18 & 18.90 \\
Multiple & 4.60 & 8.10 \\
Local communities $^{*}$ & 7.66 & 4.70 \\
\hline
\end{tabular}

${ }^{*}$ Multiple refers to multiple destinations. As per tradition, all bushpig and bushbuck carcasses were divided among the traders.

Traders stayed in the camps for up to 1 month, purchasing meat and smoking it before transporting it in bulk. Transportation was at night; local people were hired to carry the bushmeat to a pre-arranged location that was accessible by motorbike. From there the trader transported the bushmeat to Greenville by motorbike taxi, where public vehicles were hired to transport it across the country.

At the time of this survey informers working in the vicinity of the Park noted the movement of two trucks between Grand Gedeh, Rivercess and Sinoe Counties on a fortnightly basis, picking up bushmeat at pre-arranged destinations along the way. An investigation of one truck in May 2010 revealed 5-6 large sacks and eight small sacks of bushmeat, each estimated to contain 60 and 30 smoked carcasses, respectively. One small sack that was opened (Plate 1) contained body parts from three chimpanzees and one Jentink's duiker, confirming a commercial trade in protected species.

\section{Discussion}

In accordance with other studies (e.g. Foerster et al., 2011), the survey results indicate that commercial hunters in the vicinity of Sapo National Park target c. 15-20 large mammal species, particularly ungulate and primate species, which are 


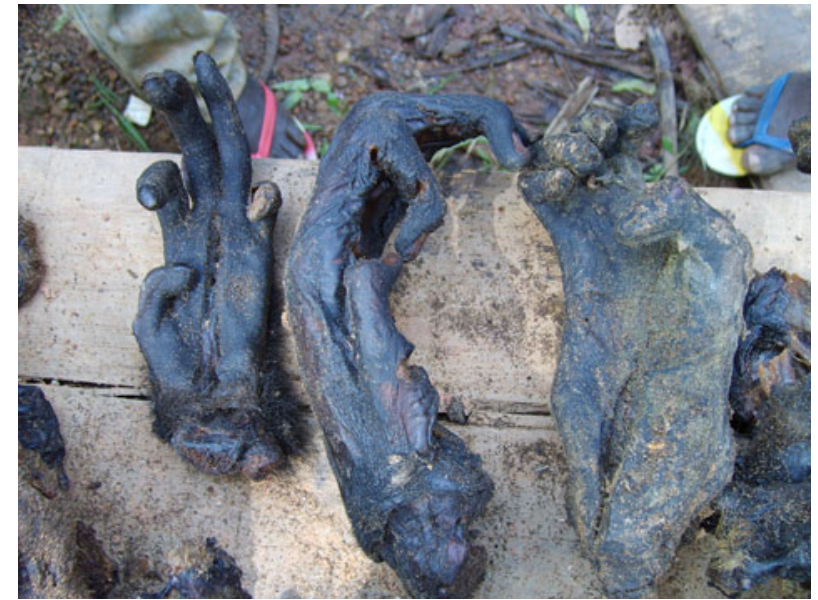

Plate 1 Hands and feet of chimpanzees Pan troglodytes verus, found in a truck transporting bushmeat to Monrovia from the south-east of Liberia.

two of three taxa targeted for human consumption in all areas where the trade has been documented (Fa \& Brown, 2009). As the composition of a hunter's catch depends largely on what is available and is related to the proximity of high forest (Hoyt, 2004), the high proportion of threatened species indicated that hunters were operating in areas that still support a high level of biodiversity. Law enforcement is weak and the risk of being caught is low, and therefore it is reasonable to assume that at least some hunting activity occurred within the Park, although hunting of some species is illegal regardless of the location.

Commercial hunting normally follows a boom and bust pattern (Bennett, 2008). Offtake increases initially when a remote area of forest is first connected to a market, followed by a rapid decline as wildlife populations are depleted. Increases in the proportion of rodents may indicate a reduction in larger, more favoured bushmeat species but although hunting from the two camps was intensive there was no clear evidence of overexploitation. The small contribution of rodents and the high proportion of hunting using shotguns suggests that larger-bodied animals were still relatively plentiful. Given incentives to overexploit the wildlife, it is doubtful that hunting was occurring within sustainable limits. It is therefore possible that commercial hunting from this location on the southern boundary of the Park had developed only recently.

The income generated by full-time hunters was considerable. It is doubtful that any alternative livelihoods exist in rural Liberia that could offer the same financial incentive as commercial hunting. Artisanal gold mining has the potential to be lucrative but monthly earnings are likely to fluctuate significantly, with the probability of earning a considerable income being small. Given that barriers to entry are low, it is interesting that not more men hunt professionally. However, rural Liberians generally describe hunting as hard and it is clearly not a lifestyle for everybody.
Furthermore, limited livelihood options mean that even low-volume hunting significantly contributes to cash incomes. Hunter-farmers can earn up to a few hundred dollars per month from hunting on a part-time subsistence basis from their homes (E. Greengrass, unpubl. data).

The camps were supplying meat to major urban centres and the greatest proportion went to Monrovia. Greenville received the next largest proportion, followed by Ganta in Nimba County, a region where the large mammal fauna has already been overexploited (ArcelorMittal, 2009; Conservation International, undated). Commercial hunting may therefore be driven in part by demand for bushmeat from urban areas. An estimated $48.2 \%$ of Liberia's human population lives in urban communities (CIA, 2014). Widespread poverty creates demand for affordable sources of protein, and this is exacerbated by the lack of commercial-scale domestic meat production or adequate alternatives in urban areas. This is an important observation; many studies have focused on the provisioning services of bushmeat and its function in alleviating poverty in the rural setting while ignoring its significance in the urban context.

Despite the necessity of bushmeat markets in providing a protein source for people who do not hunt, the trade in Monrovia may be having a disproportionate impact on wildlife in the vicinity of Sapo National Park. Chimpanzees tend to be hunted opportunistically and aspects of their behaviour (e.g. their occurrence at low density and their fission-fusion society) make them difficult to hunt, and therefore the reported harvesting of 82 chimpanzees was unexpected. Price does not appear to explain the high rate of harvesting of chimpanzees; USD 40 per carcass is similar to the price paid for other larger-bodied species. There is evidence of a demand for body parts for use in traditional medicine (Plate 1) but the magnitude of this demand is unknown. A domestic trade in live infants has generally been thought a by-product of the trade in bushmeat but there is growing evidence for an international trade in apes in the region (Ammann et al., 2013). In 2013 CITES sanctioned Guinea over international trade in great apes, sourced from a number of West and Central African countries, which has grown as a by-product of commercial hunting.

As part of the reform of the forestry sector the government of Liberia agreed in 2003 to extend the number of protected areas to cover $30 \%$ of forests. Subsequently a protected area network was proposed. Tweh et al. (2014) called for full protection status for areas of high conservation priority to meet this goal because the majority of the country's chimpanzees and other species-rich mammal communities exist outside protected areas. However, the finding that large-scale commercial hunting of protected species may occur in Sapo National Park not only undermines conservation efforts but suggests formal protection alone will not be sufficient to protect Liberia’s unique biodiversity. 
The results of this study did not appear to influence the authorities to take action to combat commercial hunting in the Park. Weak governance in the forestry sector remains a major obstacle to implementing forest management in the tropics (Zimmerman \& Kormos, 2012). Despite extensive reform in Liberia's forestry sector, institutional capacity is limited and state enforcement of comprehensive laws is weak (e.g. SDI, 2010). As elsewhere in the region, law enforcement personnel are not permitted to carry arms despite the proliferation of guns among hunters. Although in a limited area of the Park close to the Forest Development Authority park headquarters law enforcement has had a positive effect on wildlife populations (Vogt, 2011; E. Greengrass, unpubl. data), overall the proliferation of illegal activities suggests protection has been inadequate.

Since the study, private-sector investment, in particular in mining and logging around the Park, has resulted in development of the road network and transport links, and increased access to the forest, which carries other risks (e.g. it is thought that Guinea's oil palm cultivation attracted fruit bats carrying the Ebola virus; Wallace et al., 2014). As essential as they are to development, however, roads are also an essential component of the commercial bushmeat trade. The company Putu Iron Ore Mining has been exploring the Putu Mountains just north of the Park and plans to build a train line from its project site to the coast at Greenville; the train line and associated roads will circumvent the Park, transforming the area and increasing pressure on wildlife in the Park by increasing the efficiency and profitability of the trade in bushmeat. In the absence of effective protection, such developments are likely to have a disastrous effect on biodiversity in the area. This is both a biodiversity and human poverty issue. The trade poses a threat to the survival of species, and ultimately to the livelihoods of people living around the Park who rely on bushmeat to meet their nutritional and economic needs. Sapo National Park has the potential to enhance the sustainability of subsistence-level hunting outside its boundaries by functioning as a wildlife source (Bennett \& Robinson, 2000), with positive impacts for both people and wildlife, but only if its status is upheld, regulations are enforced and wildlife protected. Loss of forest wildlife to urban markets creates a food security problem for the most marginalized forest people, who cannot adapt easily to alternative sources of protein (Bennett, 2007).

A review of all Park protection efforts is needed. Efforts to regulate, monitor and control the trade consistently in the long term are imperative if species are to persist. Most importantly, although the closure of commercial camps around the Park is critical, of equal urgency is the need for Liberia to develop sectors in domestic meat production and fisheries and to establish the means to feed a growing urban population. Liberia's remaining forest and its iconic
National Park should not, and cannot, continue to supply the country's food indefinitely.

\section{Acknowledgements}

This study was funded by the Critical Ecosystem Partnership Fund (CEPF) and implemented through Fauna \& Flora International (FFI). I thank the Forestry Development Authority of the Government of Liberia, and the former Managing Directors John Woods and Moses Wogbeh, the Director of Conservation, Theo Freeman, and the former Park Warden and Acting Park Warden of Sapo National Park, Blamah Goll and John Konie. I extend my appreciation to all staff and consultants at FFI Liberia. In particular, I thank Chloe Hodgkinson and Kathryn Shutt of FFI for their advice. Most especially I thank Konrowh Wesseh, who collected the data, and my host community, Jalays Town.

\section{References}

Ammann, K., Sparwasser, K., Cockayne, N. \& Schoene, C. (2013) The Conakry Connection. Pax Animalis, Gerzensee, Switzerland.

Arcelor Mittal (2009) Nimba Western Area Iron Ore Deposits, Liberia Environmental Baseline Studies. Volume 3: Flora and Fauna. Unpublished report. ArcelorMittal, Monrovia, Liberia.

Beaune, D., Bretagnolle, F., Bollache, L., Hohmann, G., Surbeck, M. \& Fruth, B. (2013) Seed dispersal strategies and the threat of defaunation in a Congo forest. Biodiversity and Conservation, 22, 225-238.

Bennett, E.L. (2007) Hunting, wildlife trade and wildlife consumption patterns in Asia. In Bushmeat and Livelihoods: Wildlife Management and Poverty Reduction (eds G. Davies \& D. Brown), pp. 241-249. Blackwell Publishing, Oxford, UK.

Bennett, E.L. (2008) Hunting and Trade of Bushmeat in Central Africa. A Review of Conservation, Livelihood and Policy Implications. World Bank, Washington, DC, USA.

Bennett, E.L. \& Robinson, J.G. (200o) Hunting of Wildlife in Tropical Forests. Implications for Biodiversity and Forest Peoples. Environment Department Papers, No. 76. World Bank, Washington, DC, USA.

Christie, T., Steininger, M.K., Juhn, D. \& Peal, A. (2007) Fragmentation and clearance of Liberia's forests during 1986-200o. Oryx, 41, 539-543.

Cia (Central Intelligence Agency) (2014) The World Factbook: Liberia. Https://www.cia.gov/library/publications/the-worldfactbook/geos/li.html [accessed 10 August 2014].

Collen, B., Howard, R., Konie, J., D aniel, O. \& Rist, J. (2011) Field surveys for the Endangered pygmy hippopotamus Choeropsis liberiensis in Sapo National Park, Liberia. Oryx, 45, 35-37.

Conservation International (undated) Further Ecological Studies as Part of the Environmental and Social Impact Assessment for ArcelorMittal Liberia: Bushmeat and Bio-monitoring Studies in the Northern Nimba Conservation Area. Unpublished report. ArcelorMittal, Monrovia, Liberia.

Covey, R. \& McGraw, W.S. (2014) Monkeys in a West African bushmeat market: implications for cercopithecid conservation in eastern Liberia. Tropical Conservation Science, 7, 115-125. 
FA, J.E. \& BROWN, D. (2009) Impacts of hunting on mammals in African tropical moist forests: a review and synthesis. Mammal Review, 39, 231-264.

Foerster, S., Wilkie, D.S., Morelli, G.A., Demmer, J., Starkey, M., Telfer, P. et al. (2011) Correlates of bushmeat hunting among remote rural households in Gabon, Central Africa. Conservation Biology, 26, 335-344.

Greengrass, E.J. (2013) A survey of small carnivores in the Putu Mountains, southeast Liberia. Small Carnivore Conservation, 48, $30-36$.

Henschel, P., Hunter, L.T.B., Coad, L., Abernethy, K.A. \& Mühlenberg, M. (2011) Leopard prey choice in the Congo Basin rainforest suggests exploitative competition with human bushmeat hunters. Journal of Zoology, 285, 11-20.

Hoy t, R. (2004) Wild Meat Harvest and Trade in Liberia: Managing Biodiversity, Economic and Social Impacts. Overseas Development Institute Wildlife Policy Briefing, Number 6. Overseas Development Institute, London, UK.

IUCN (2014) IUCN Red List of Threatened Species. Http://www. iucnredlist.org [accessed 12 August 2014].

Kayjay, G.S.T. (2010) Assessment Tour at the Sapo National Park from January 13th to 22nd 2010. Unpublished report. Forestry Development Authority, Monrovia, Liberia.

Kingdon, J. (1997) The Kingdon Guide to African Mammals. Academic Press, San Diego, USA.

MPEA (Ministry of Planning and Economic Affairs) (2010) Liberia's Vision for Accelerating Economic Growth. A Development Corridor Desk Study. Unpublished report. MPEA/USAID, Monrovia, Liberia.

Myers, N., Mittermeier, R.A., Mittermeier, C.G., Da Fonseca, G.A.B. \& KENT, J. (2000) Biodiversity hotspots for conservation priorities. Nature, 403, 853-858.

N’Goran, P.K.N., Kouakou, C.Y. \& Herbinger, I. (2010) Report on the Population Survey and Monitoring of Chimpanzees in Sapo National Park, Liberia (June-December 2009).
Unpublished report. Wild Chimpanzee Foundation, Abidjan, Côte d'Ivoire.

Peres, C.A. (2010) Overharvesting. In Conservation Biology for All (eds N.S. Sodhi \& P.R. Ehrlich), pp. 107-130. Oxford University Press, Oxford, UK.

SDi (Sustainable Development Institute) (2010) Liberia-The Promise Betrayed. Http://www.sdiliberia.org/sites/default/files/ publications/2010_Liberia_The_Promise_Betrayed.pdf [accessed 19 August 2014].

Tweh, C.G., Lormie, M.M., Koua Kou, C.Y., Hillers, A., Kühl, H.S. \& Junker, J. (2014) Conservation status of chimpanzees Pan troglodytes verus and other large mammals in Liberia: a nationwide survey. Oryx. Http://dx.doi.org/10.1017/So030605313001191 [accessed 23 February 2015].

Vogt, M. (2011) Bio-monitoring and Research Programme, Sapo National Park: Results of Sapo National Park Bio-monitoring Programme 2007-2009. Unpublished report. Fauna \& Flora International, Cambridge, UK

Wait Kuwait, W.E. (2003) Report on the First Year of Operation of a Community-based Bio-monitoring Programme in and Around Sapo National Park, Sinoe County, Liberia. Unpublished report. Fauna \& Flora International, Cambridge, UK.

Wallace, R.G., Gilbert, M., Wallace, R., Pittiglio, C., Matтioli, R. \& Kock, R. (2014) Did Ebola emerge in West Africa by a policy-driven phase change in agroecology? Environment and Planning A, 46, 2533-2542.

Zimmerman, B.L. \& Kormos, C.F. (2012) Prospects for sustainable logging in tropical forests. BioScience, 62, 479-487.

\section{Biographical sketch}

Elizabeth Greengrass is interested in the conservation of the large mammal fauna of the forests of West and Central Africa and the impacts of natural resource extraction on biodiversity. 